\title{
The Controversy in Pedagogical Competence of Early Childhood Education Teachers Towards the Policy of Indonesia National Education Ministry
}

\begin{abstract}
Buyung Surahman ${ }^{1 *}$, Mela Aziza ${ }^{2}$
${ }^{1}$ Pascasarjana, Institut Agama Islam Negeri Bengkulu, Bengkulu, Indonesia

${ }^{2}$ Tadris Matematika, Institut Agama Islam Negeri Bengkulu, Bengkulu, Indonesia

e-mail: buyungsurahman@iainbengkulu.ac.id, mela.aziza@iainbengkulu.ac.id

Abstract

The study aims to find out and describe what percentage (\%) of pedagogical competence controversy of Early Childhood Education teachers in the teaching and learning process to the policy of Indonesia National Education Ministry. This study used a descriptive qualitative method. Data collection techniques were observation, interview and questionnaire. The validity test used the product moment formula while the reliability test used Cronbach's alpha formula. The results of the study showed that mastering characteristics of students is 10,5\%; mastering learning theories and learning principles that educating is 10\%; curriculum development is 9,1\%; learning activities that educating is 20,02\%; potential development of students is 7,4\%; communication with students is 4,5\%; and evaluation and evaluation is $8,0 \%$. It can be concluced that the biggest controversy was found in the mastery of educational learning activities while the smallest mastery of communication.
\end{abstract}

Keywords: Early Childhood Education, Pedagogical Competence Controversy

\section{Introduction}

Early Childhood Education is a form of education and guidance given to a child from birth to six years in the form of physical and spiritual stimuli in preparation for children to enter the next level of education where one of the educational units is kindergarten (Ismawati \& Prasetyo, 2021; Khotimah et al., 2021; Wandi \& Mayar, 2020). Learning is done at this level and is considered very important is learning to improve the ability of Literacy and Numeration of children as the main provision to enter the level of basic education (Fahmi et al., 2021; Widayati et al., 2021; Arsa et al., 2019; Widodo \& Ruhaena, 2018). Seeing this urgency, the Early Childhood Education educator or teacher must have a teacher's basic competencies, especially pedagogical competencies. By having good pedagogical competence, teachers are expected to be able to prepare children to enter elementary school, especially in developing children's abilities related to reading and arithmetic.

Teachers and Lecturers explained that pedagogical competence is the ability of a teacher or educator in managing student learning (Babuta \& Rahmat, 2019; Setiawan \& Sitorus, 2017). Teacher pedagogical competence will affect teacher performance namely, beliefs and values; skills; experience; personality characteristics; emotional issues; and intellectual abilities (Mena et al., 2016; Tanama et al., 2016). These competencies depend on cognitive thinking such as conceptual thinking and analytical thinking.

However, the facts in Indonesia today, there are many controversies in the pedagogical competence of teachers against learning, such as teachers who teach kindergarten are not supported by their education quallification, for example they are senior high schoolar or vocational high schools graduates (Andriana et al., 2018; Meutia \& Mursita, 2018). The results of the Teacher Competency Test (UKG) which were carried out in 2015 have been in the form of a Learning Teacher Program with a target of achieving an average score of 65 and the UKG average value of kindergarten teachers in 2015 to 2017 continues to increase, meaning that the improvement in value is one way of self-development of educators in increasing

\footnotetext{
${ }^{*}$ Corresponding author.

Received 29 July 2020; Accepted 23 August 2020; Available online 01 September 2020

(C) 2020 JPI. All Rights Reserved
}

Jurnal Pendidikan Indonesia (JPI) | 446 
competence so that they become professional teachers (Maiza \& Nurhafizah, 2019). Based on this, it is clear that teacher development activities are very important.

In addition, teacher pedagogical competence has not met the expectations. This is indicated by the Center for Early Childhood Education Statistics in 2018, stating that the total of Early Childhood Education teachers in Indonesia is 750.769 (31.721 junior high school graduates, 366.818 high school graduates, 238.003 Bachelor Degree (S1 / D4) graduates, and 5.671 graduates of Postgraduated programs (S2 and S3). Early Childhood Education teachers in the Bengkulu Provention whose education was not yet equal to S1 totaled $1.396(44,4 \%)$ of the total number of 3.143 teachers. The low pedagogical competence of Early Childhood Education teachers is not only influenced by the lack of teacher teaching and training experience, but the qualification of teacher education also plays an important role in mastering pedagogical competence. This is evident from the research results conducted by (Sum \& Taran, 2020) stated that There are still many Early Childhood teachers who do not qualify for Bachelor Degree (S1) Early Childhood Education Department or do not have one understanding of Early Childhood Education thus causing the lack of pedagogical competence that is owned ultimately affects the quality of the learning process for children, learning becomes unpleasant and the assessment of learning by the teacher has not been able to describe developments that cover all aspects of child development. Research conducted by (Andriana et al., 2018) stated that the performance of Early Childhood Education teachers in terms of the qualifications of educators, teaching experience, and training in Muara Bengkulu showing that teachers having Bachelor degree on Early Childhood Education qualifications in the excellent category with grades an average of $83,3 \%$, they did not graduate from Early Childhood Education program is in the good category with a value of $74,4 \%$, and high school graduates are in the good category with a value of $70 \%$.

The competencies that early childhood teachers must possess must at least meet the standards and with this competence, the teacher is considered an exemplary personal figure because he is able to show virtues in the practice of his life behavior and learning can be carried out properly (Dewi \& Suryana, 2020; Rosyati et al., 2020; Junanto \& Kusna, 2018). This study aims to find out and describe what percentage (\%) of pedagogical competence controversy of Early Childhood Education teachers in the teaching and learning process to the policy of Indonesia National Education Ministry.

\section{Method}

This type of research is field research, using descriptive methods and survey methods. Descriptive method is used to analyze the results of the study, while the survey method is used to take samples from the population using a questionnaire as a data collection tool related to the controversy of pedagogical competence of Early Childhood Education teachers in the teaching and learning process towards the policy of the Ministry of Indonesia National Education.

The population in this study was all Early Childhood Education teachers who were Civil Servants in Bengkulu city totaling 111 people and Early Childhood Education teachers who were Civil Servants in Kepahiang district amounted to 44 people. Samples were taken 25\% of each population so the research samples for Bengkulu city were $25 \% \times 111=27.75$ which was about 28. The research samples for kepahiang district were $25 \% \times 63=15.75$ rounding to 16 . Then the number of samples from the two study sites were $28+16=44$ people.

Data collection techniques namely observation, interviews, and filling out the questionnaire. First, the data were collected through two days of observation to the research sites of several respondents in the city of Bengkulu and in the district of Kepahiang. After observation, researchers also conducted interviews with some of these respondents. Second, data is collected through filling instruments in the form of online questionnaires. The questionnaires contained the questions in accordance with the lattice that refers to the research variables and has been done validation and reliability.

Data analysis techniques in the study used percentage analysis to see how likely the frequency of respondents' answers. The technique follows the following procedures: checking the data and checking the completeness of the respondent's answers; classifying data based 
on seven criteria to facilitate data analysis; tabulating data based on the classification made; calculate the frequency of answers; and calculate the percentage of each data obtained. The data obtained will be calculated using the formula $P=F N \times 100 \%$, then the results of the calculation of data from the formula, entered into the table in accordance with the criteria. The criteria used refer to the Likert scale 1-4 in Sugiono's book (2009: 135) presented in Table 1.

Table 1. The Score of Early Childhood Education Teacher Pedagogical Competency Questionnaire

\begin{tabular}{cc}
\hline The Alternative of Answers & Score \\
\hline Always & 4 \\
Often & 3 \\
Sometimes & 2 \\
Never & 1 \\
\hline
\end{tabular}

\section{Result and Discussion}

\section{Result}

In this study data were collected by observation, interview and online questionnaire. From the three data collection techniques, the following are found.

\section{Observation Results}

Observations were made at the place of several respondents in the city of Bengkulu and Kepahiang district, during the observation the researchers saw directly the learning process in Early Childhood Institutions where the respondents taught. The researcher also observed the number of teachers, the background of teacher education qualifications, the learning tools that teachers used included lesson Plans and Syllabus, and the availability of infrastructure, especially books and references in the library. Due to the effectiveness and efficiency of time, observations should only be made at two Early Childhood Institutions in Bengkulu City and two Early Childhood Institutions in Kepahiang District. The findings during the observation in Table 2.

Table 2. The observation results of Early Childhood Institutions

\begin{tabular}{|c|c|c|c|c|c|c|}
\hline $\begin{array}{l}\text { Place of } \\
\text { Research }\end{array}$ & $\begin{array}{l}\text { Name of } \\
\text { Institution }\end{array}$ & $\begin{array}{l}\text { Number } \\
\text { of } \\
\text { Teachers }\end{array}$ & $\begin{array}{l}\text { Number } \\
\text { of } \\
\text { Undergra } \\
\text { duate } \\
\text { Teachers } \\
\end{array}$ & $\begin{array}{l}\text { Number of } \\
\text { High } \\
\text { School } \\
\text { Graduates } \\
\text { Teachers } \\
\end{array}$ & $\begin{array}{l}\text { Learning } \\
\text { Tools } \\
\text { (Planning } \\
\text { to Teach) }\end{array}$ & Library \\
\hline \multirow[t]{2}{*}{$\begin{array}{l}\text { Bengkulu } \\
\text { City }\end{array}$} & $\begin{array}{l}\text { PAUD } \\
\text { Bilqis }\end{array}$ & 5 & 2 & 3 & $\begin{array}{l}\text { Existing } \\
\text { and } \\
\text { Complete }\end{array}$ & $\begin{array}{l}\text { References are } \\
\text { all available but } \\
\text { most are still } \\
\text { from the Website }\end{array}$ \\
\hline & $\begin{array}{l}\text { PAUD } \\
\text { Tunas } \\
\text { Bangsa }\end{array}$ & 6 & 4 & 2 & $\begin{array}{l}\text { Existing } \\
\text { and } \\
\text { Complete }\end{array}$ & $\begin{array}{l}\text { References are } \\
\text { all available but } \\
\text { there are still } \\
\text { those that are } \\
\text { not from trusted } \\
\text { sources }\end{array}$ \\
\hline \multirow[t]{2}{*}{$\begin{array}{l}\text { Kepahian } \\
\text { g District }\end{array}$} & $\begin{array}{l}\text { PAUD As- } \\
\text { Syifa }\end{array}$ & 3 & 2 & 1 & $\begin{array}{l}\text { Existing } \\
\text { and } \\
\text { Complete }\end{array}$ & $\begin{array}{l}\text { References are } \\
\text { all available but } \\
\text { all from the } \\
\text { Website }\end{array}$ \\
\hline & $\begin{array}{l}\text { PAUD Al- } \\
\text { Madani }\end{array}$ & 6 & 1 & 5 & $\begin{array}{l}\text { Existing but } \\
\text { incomplete }\end{array}$ & $\begin{array}{l}\text { References are } \\
\text { partially } \\
\text { available }\end{array}$ \\
\hline
\end{tabular}


Based on these observations it was found that the majority of teachers in PAUD ALMADANI in Kepahiang District were high school graduates. The availability of learning tools and libraries was also still not optimal.

\section{Interview Results}

After conducting observations, researchers conducted interviews with respondents in the four Early Childhood Institutions both in the city of Bengkulu and in the District of Kepahiang. Interviews use open-ended questions and recording of each interviewee's answers is done. Interviews were conducted to confirm the observations found. Some of the results of interviews conducted with respondents in the city of Bengkulu are shown below.

Researcher: "Why did you make learning tools (lesson plans, syllabus, and teaching materials) by taking them from online sources?"

Respondent: "Because it's more practical and I don't need to think and retype again"

It can be seen that from the results of the above interview some teachers chose to take the learning tools directly on the internet and then use them.

Researcher: "Is there no obligation from the head of this school regarding the source of learning tools (lesson plans, syllabus, and teaching materials)?"

Respondent: "No, because the most important is the set of learning used by the teacher"

From the interview results above it was found that there has been no monitoring of the sources used by teachers in making learning tools in the Early Childhood Institutions in Bengkulu city.

Researcher: "Do you have any reading sources related to learning and teaching theories in this school Library?"

Respondent: "This school have no those books. There are only books for kindergarten learning but the teacher's reading material is not yet available"

From the interview results above it was found that there were no books available realted to learning theory in the library of the Early Childhood Institutions where they taught so they did not yet have a reading source to increase knowledge.

Some of the results of interviews conducted with respondents in Kepahiang District are shown below.

Researcher : "Do you have learning tools (lesson plans, syllabus and teaching materials) as guidance when teaching?"

Respondent1 : "Yes, I have"

Respondent2 : "I don't have it yet"

Researcher : "Why?"

Respondent2 : "I have not been able to make it"

It can be seen that from the results of the above interviews some teachers have not been able to make learning tools for guiding them teaching.

Researcher : "Do you have any reading sources related to learning and teaching theories in this school Library?"

Respondent: "No, there are some kindergarten learning books. Even these are still very little"

From the interview results above, it was found that there were not many textbooks or books on learning theory or teaching in the Early Childhood Institutions library in Kepahiang district. 


\section{Online Questionnaire Results}

The questionnaire used was an online questionnaire using a Google form consisting of 30 questions that were made based on seven criteria based on the policy of the Ministry of Indonesia National Education in 2010. There were 44 respondents who filled out the questionnaire both from Bengkulu City and Kepahiang District.

Based on the results of the writer's analysis of the controversy of pedadgodical competence of Early Childhood Education teachers with the policy of the Ministry of Indonesia National Education in 2010 about seven criteria related to: mastering the characteristics of students; mastering learning theory and principles of learning that educate; mastering curriculum development; mastering learning activities that educate; mastering the development of students' potential; mastering communication with students; and mastering assessment and evaluation, as shown in the following Table 3.

Table 3. The Online Questionnaire results of Teachers' Pedagogical competence

\begin{tabular}{|c|c|c|}
\hline No & Statements & $\begin{array}{l}\text { The percentage of } \\
\text { Controversy (The total } \\
\text { percentage of answers } \\
\text { that say "Never" and } \\
\text { "Sometimes") }\end{array}$ \\
\hline 1 & Teacher masters the characteristics of students & $10,5 \%$ \\
\hline 2 & $\begin{array}{l}\text { Teacher masters learning theory and principles of } \\
\text { learning that educate }\end{array}$ & $10 \%$ \\
\hline 3 & Teacher masters curriculum development & $9,1 \%$ \\
\hline 4 & Teacher masters learning activities that educate & $20,02 \%$ \\
\hline 5 & $\begin{array}{l}\text { Teacher masters the development of students' } \\
\text { potential }\end{array}$ & $7,35 \%$ \\
\hline 6 & Teacher masters communication with students & $4,5 \%$ \\
\hline 7 & $\begin{array}{l}\text { Teacher masters assessment and evaluation } \\
\text { Total }\end{array}$ & $\begin{array}{c}8 \% \\
69,47 \%\end{array}$ \\
\hline
\end{tabular}

The results of the assessment criteria in the table above indicate that, the highest controversy is in the fourth criterion, "Teacher masters learning activities that educate" with a percentage of $20.02 \%$. The lowest controversy is in the fifth criterion, "Teacher masters the development of students' potential", with a $4.5 \%$ presentation. Based on the data in the table, it can be calculated that the controversy of pedagogical competence of Early Childhood Education teachers in Kepahiang district and Bengkulu city towards the policy of Indonesia National Education Ministry with an average calculation of 69.07: $7=9.92=10 \%$ (Rounding up).

\section{Discussion}

The controversy of pedadogical competence of Early Childhood Education teachers that will be discussed is related to differences, discrepancies, and or weaknesses of teachers in conducting the learning process so as to cause controversy between the seven criteria pedagogical competence of Early Childhood Education teachers in the Ministry of National Education (Kemendiknas) policy in 2010 with the application of learning activities conducted by the teachers in schools.

First, mastering the characteristics of students. Based on the results of the author's research conducted in Bengkulu with 44 Early Childhood Education teachers, the average results of pedagogical competence of Early Childhood Education teachers in mastering characteristics of students are as follows: $1 \%$ never, $9.5 \%$ sometimes, $45 \%$ often, and $44.5 \%$ always. If the categories of statements "never" and "sometimes" are added together, then these become $1 \%+9.5 \%=10.5 \%$. It means that out of the number of teachers 44 , there are 5 teachers who are controversial or lack mastering the characteristics of students. The five 
teachers are a controversy in mastering the characteristics of students against the Policy of Indonesia National Education Ministry.

The controversy of teacher pedagogical competence will reappear if it does not master the characteristics of early childhood. The characteristics of early childhood are very fast developing, so that when the teacher graduated understand it will have an impact on the child itself. The development of early childhood characteristics is very fast and runs rapidly, so that if parents and teachers are late paying attention it will have a negative impact on further development (Zhang et al., 2018; Fatimah \& Rohmah, 2016). To overcome the weaknesses of pedagogical competence parents and teachers really need to know the characteristics of early childhood development according to their age level (Liempd et al., 2020). By understanding the characteristics of early childhood development, the teacher and parents can place themselves in the child's development in other words, not impose personal will on the child because it will greatly affect the future development.

Second, the teacher's pedagogical competence in mastering learning theories and principles of learning that educates. Based on the author's research, it turns out that the teacher is in charge of learning theory and the principles of learning that educate as follows: $0 \%$ never, $10 \%$ sometimes, $42.3 \%$ often, and $47.7 \%$ always. This data shows that from teachers 44 there were 4 teachers who did not or did not master the theory of learning and the principles of teaching that educated, which caused controversy over the policies of the National Education Ministry. Based on the results of observations of researchers to the library in Early Childhood Institutions in the city of Bengkulu, it turns out the books on learning theory are very lacking, even hard to find, which have books for student learning. Therefore, the tendency of teachers to master the theory of learning and learning principles that is not very high.

Other factors that influence the weaknesses of teachers' pedagogical competence in the field of mastering learning theory and principles of learning that educate include: teacher education qualifications and Early Childhood Education teachers have not maximally utilized technology related to the presentation of learning. Based on the documents from 2 Early Childhood Education Institutions in the city of Bengkulu, it was found that there are still 5 teachers, who have not yet graduated from Undergraduate program. These 5 teachers are less inclined to master learning theory, because the qualifications of teacher education strongly support the pedagogical competence of teachers. Research conducted by (Sum \& Taran, 2020) stated that in Manggarai district revealed that: the academic qualifications of Early Childhood Education teachers affect the ability, knowledge and understanding of teachers towards students; there are still many Early Childhood Education institutions that lack the ability to prepare learning plans; the lack of pedagogical competence possessed ultimately affects the quality of the learning process for students; and the lack of teacher learning designs inhibits children's developmental aspect.

However, this low teacher competence can be overcome, such as government programs in addressing low educational qualifications and in improving Early Childhood Education teacher competencies delivered by the Director General of Teachers and Education Personnel Hamid Muhammad said, the government has a program of granting aid for Early Childhood Education teachers, namely the accelerated process of college completion to obtain Bachelor degree. The number of Early Childhood Education Teachers who were given assistance in 2017 was 19.819 teachers, the teacher will be distributed from several universities in Indonesia, with Bachelor degree in Early Childhood Education Programs, Community Education, and Counseling Guidance

Besides education qualifications of Early Childhood Education Teachers, the teachers also have not yet maximally utilizing technology related to the presentation of learning. From observations researchers have found that 2 Early Childhood Education Institutions in Kepahiang still teach manually. This will affect the pedagogical competence of teachers in educating students. The research conducted by (Ayuni \& Setiawati, 2019) showed that Kebun Buah media affected counting ability on children aged 5-6 years, the results of post-test counting ability of children in the experimental class using Kebun Buah media increased to 88 in average while in the control class using a number card media obtained an average 78.9. Other research was conducted by (Aprinawati, 2017) showed that using a series of drawing 
media can develop the potential for child speech development and increase vocabulary mastery.

Third, teacher pedagogical competence in curriculum development. Based on the results of the author's research, the competence of Early Childhood Education teachers on curriculum development with an average grade is as follows: $0 \%$ never, $9.1 \%$ sometimes, $46.9 \%$ often, and $44.1 \%$ always. If this data is grouped the value has never been and sometimes it results in $0 \%+9.1 \%=9.1 \%$. Thus $9.1 \%$ of the total number of teachers 44 ie 4 people is the number of teachers who are controversial about curriculum development.

The Early Childhood Education Curriculum should always develop according to the needs of the environmental community and include everyday activities for young children. The development of this curriculum is in line with the research result conducted by (Rahelly, 2018) stated that the implementation of the 2013 curriculum is very effective if it is planned that school principals and teachers start from implementing the Semester Planning Learning Tool, Weekly Learning Implementation Plan and assessment planning. The development of the Early Childhood Education Curriculum is still weak and needs to be developed by teachers and need a good management structure. There are 4 processes of good curriculum management activities, namely planning, organizing, implementing, and monitoring and evaluating the curriculum (Rahelly, 2018). Curriculum development must also be based on the principles of early childhood development, namely: (1) the process of learning activities in early childhood must be carried out based on the principles through play; (2) implemented in a conducive and innovative environment both inside and outside the room; (3) implemented with an integrated approach; and (4) must be directed towards developing the potential of intelligence as a whole and integrated (3) carried out with an integrated approach; (4) must be directed towards developing the potential of intelligence as a whole and integrated (Botutihe, 2020; Rahardjo, 2016; Hasanah, 2015).

Solutions so that the curriculum can develop properly, the teachers must conduct education and training in curriculum development. Early Childhood Education Teacher Curriculum training in Grabak sub-district effectively was very significant to the reaction of participants, understanding material, behavior change, and impact on school (Fauziarti \& Soedarsono, 2014). A good curriculum for Early Childhood Education is a curriculum that is compiled should involve teachers, parents, school committees, and community involvement (Botutihe, 2020; Yati \& Yaswinda, 2020). When these 4 elements unite in developing the curriculum, there will be mutual support in achieving learning outcomes.

Fourth, the teacher's pedagogical competence in teaching and learning activities. Based on the authors' research results, the average pedagogical competence of teachers in teaching and learning activities is as follows: $0.92 \%$ never, $19.1 \%$ sometimes, $39.6 \%$ often, and $40 \%$ always. If this data is grouped the value is never and sometimes it results in $0.92 \%$ $+19.1 \%=20.02 \%$. Thus $20.02 \%$ of the total number of teachers 44 , there are 8.8 (rounding up) $=9$, this is the number of teachers who are controversial about curriculum development based on the policy of Indonesia National Education Ministry. Educating learning activities should have been prepared in the learning plan programmed by the teacher before teaching. The learning program is arranged based on aspects of development, the needs of students and contains learning that educates. The preparation of learning programs that are in accordance with aspects of child development, as follows (1) learning planning is arranged in the form of syllabus, semester planning, weekly planning and daily planning. Learning planning is prepared by considering the level of child development, aspects of child development, children's needs, interests and characteristics of children; (2) the implementation of learning in the Rutosoro Kindergarten begins with the welcoming of the child by the teacher, introduction (moving together, praying, presence, questions and answers about themes and sub-themes), core activities, eating and resting, closing. Implementation of learning using methods that are adapted to the theme of the principle of play while learning; and (3) assessment of learning is carried out at any time from the time children start until they finish the school through assignments, conversations, observations, performance, work, and portfolios (Sum \& Taran, 2020; Apriyanti, 2017). 
Learning activities that educate this need to be done by the teacher, because this learning aims to make changes in attitudes towards students towards teaching, such as changes in attitudes and social changes. Social development emotional children through social interactions with peers include: (1) children share with peers; (2) children obey the rules that apply in the game; (3) children play with peers; and (4) children show manners and manners in accordance with local socio-cultural values (Ananda \& Fadhilaturrahmi, 2018; Nurjannah, 2017). There are children who deviate behavior such as hitting, pushing, taunting and kicking. However, deviations in behavior by children in Early Childhood Education Nurul Hidayah Lampuk Village, Aceh Besar Regency can still be educated in a better direction. When children make a deviation of behavior towards their peers, the teacher always advises and gives direction. It is expected that parents do not prohibit children from playing with peers because peers are a factor in emotional social development. However, it is still under the supervision of parents or teachers.

To improve pedagogical competence, teachers should have high motivation in providing learning material to their students. Research conducted by (Halim Yustiyawan et al., 2016) stated that there is a direct relationship between career development with the performance teachers; between career development with the motivation teachers; between competence professional with the performance teachers; between competence professional with the motivation teachers. Early Childhood Education teachers must understand pedagogical competence because this is related to the management of learning which will later have an impact on the success of an education (Ciptaningtyas et al., 2020; Mundia Sari \& Setiawan, 2020). In this literature review will explain how important pedagogical competence is for Early Childhood Education teachers as well as the benefits of pedagogical competence for teachers and students alike.

Fifth, the development of students' potential. Based on the results of the author's research, the average pedagogical competence of teachers in developing the potential of students is: $0 \%$ never, $7.35 \%$ sometimes, $47.2 \%$ often, and $45.5 \%$ always. The percentage that was never and sometimes is $7.35 \%$. It means that there are 3 Early Childhood Education teachers out of a total of 44 teachers. Thus controversy over the development of potential learners. To develop students' potential, the teacher should identify the children's potential, because the children's potential is different, therefore before developing the child's potential, the teacher already knows the potential of the student. There are 7 ways to improve children's potential, namely: (1) recognize the child's potential, namely observing and identifying the child's potential through for example, the speed of speaking, playing, receiving information, speed of walking; (2) provide appropriate stimulation, in the form of stimuli, play opportunities, learning facilities, or which stimulate children to learn; (3) give support to children about a number of things such as, giving problems, challenges, excitement, but do not forget to give full attention so that he feels comfortable; (4) give praise in the form of motivation when he successfully works; (5) encourage children to be creative and provide facilities for children to imagine; (6) direct the child, for example if he likes to read, give reading books; and (7) encourage children to learn and as parents have to learn also give examples to children (Nihayah, 2015).

The development of students' potential is not enough to give theoretically only, such as giving advice or giving verbal instructions, but need to act or action. Research conducted by (Anggraini et al., 2020) showed that the application of problem solving strategies using media "Maze" can improve cognitive ability with aspects of problem solving consists of the ability to analyze problems, timeliness in solving problems and the ability to connect. This is evidenced by children's cognitive skills increasing with $75 \%$ mastery learning and an average of 3.89 results. Research conducted by (Watini, 2019) stated that with an increase in science learning outcomes with contextual approach the percentage of acquisition in cycle I was $58.5 \%$ cognitive domain, affective domain $47.1 \%$, psychomotor domain $56.1 \%$. In cycle II it was found that the cognitive domain was $66.7 \%$, the affective domain was $59 \%$, the psychomotor domain was $65.7 \%$. Whereas in cycle III, the cognitive domain was $78.9 \%$, the affective domain was $84.1 \%$, the psychomotor domain was $84.3 \%$. 
Sixth, communication with students. The results of the author's research in the field of communication with students from respondents 44 Early Childhood Education teachers with an average grade and category as follows: $0 \%$ never; $4.5 \%$ sometimes; $45.5 \%$ often; and $50 \%$ always. The number of percent qualifications that answered "never" and "sometimes" is $0 \%+$ $4.5 \%=4.5 \%$. So, the controversy of communication with students is only $4.5 \%$ of 44 teachers. This shows that Early Childhood Education teachers have communicated well with students.

Many ways and time that can be used properly by teachers in communicating with students, such as the research results conducted by (Azzahra et al., 2019) conclude that good communication patterns carried out by teachers during the learning process produce stimulus aspects of children's growth and development. Research conducted by (Aulina, 2018) showed that the application of the Whole Brain Teaching method can improve early childhood communication through the following principles: (1) teacher's call to the class; (2) teaching while doing meaningful symbolic movements; (3) teaching children to each other; (4) mimicking the teacher's gestures and explanations; and (5) teaching friends in turn.

The means of communication between teachers and students can be built through the media, in line with the research results conducted by (Prasanti \& Fitriani, 2018) stated that to build effective early childhood communication, namely: (1) Early Childhood Education teachers as communicators must have patient characteristics, willing sacrifice, attention, assertive, and able to attract early childhood attention; (2) the presence of media used to achieve communication between children and children or children and teachers; and (3) Early Childhood Education teachers must understand the diverse character of students. Not all means prepared by teachers in communicating to their students will work well, because Robbins (2008) states there are several obstacles in communication including filtering information, choosing perceptions, information overload, emotions, language, silence (lack of information), anxiety in communicating and lying. Several causes of communication anxiety including: (a) lack of communication skills and experience; (b) subordinate status (feeling others know or are superior); (c) degree of evaluation (afraid to communicate because of evaluation); (d) degree of conspicuousness (Level of being the center of attention); (e) degree of unpredictability (being in a situation that is hard to imagine); (e) degree of dissimilarity (feeling different from people around); and (g) prior success and failures (Inikah, 2015; Munir, 2016).

The teacher before communicating with students certainly needs to know is the condition of students at that time, because if students have many problems then communication will not run normally. This is supported by the results of research Damayanti, and Purnamasari (2019), showed a correlation value $r=0.819(p=<0.01)$, meaning that there is a positive relationship between communication barriers with stress in children. In addition, teachers also have barriers to communication during the learning process, as the research results conducted by (Febrianta \& Fauzan, 2019) showed that the barriers to teacher communication in the learning process are as follows: there are 3 teachers $(11.54 \%)$ in the excellent category, 3 teachers (11.54\%) in the good category, 13 teachers $(46.15 \%)$ in the medium category, 5 teachers (19.23\%) in the poor category, 3 teachers $(11.54 \%)$ in the very poor category.

The role of communication for students is needed from an early age, because communication is an introduction in expressing something. Therefore, communication for students is very important and relevant. There are at least 4 interpersonal communication roles, namely: (1) interpersonal communication can help the intellectual and social development of individuals; (2) a person's identity and identity will be formed through communication; (3) understanding reality; and (d) mental health (Komara, 2016; Rahmat \& Maulana, 2016).

Seventh, assessment and evaluation. Based on the results of the author's research, the average value of the evaluation and evaluation section shows the following: $0 \%$ never, $8 \%$ sometimes, $43 \%$ often, and $49 \%$ always. This data illustrates that there are 44 Early Childhood Education teachers, only $8 \%$ or 5 who contradict the assessment and evaluation of the Ministry of National Education's policies. Assessments and evaluations need to be planned from the beginning by the teacher because the evaluation is carried out from the beginning of learning, 
the learning process, and the end of learning. The standard evaluation are: (1) the assessment is carried out in three stages, namely, daily evaluation, monthly evaluation, and semester evaluation; (2) types of assessment instruments used through observation, anecdotal records, conversations, performance, assessment of works, portfolios, and informal tests; and (3) reporting daily assessments using the help of social media groups (Mundia Sari \& Setiawan, 2020; Janus \& Brinkman, 2010). Reporting monthly assessments through meetings with parents showing the portfolio of children, while reporting semester assessments using report cards from informal results delivered through parents.

The objectives of the assessment are achieved, teachers should have knowledge of various assessment methods and techniques so that they have the skills to choose and use the methods and techniques that are considered most appropriate to the objectives and learning process, as well as learning experiences that have been set (Mundia Sari \& Setiawan, 2020; Nurdin \& Anhusadar, 2020). Improving teacher competence in the field of evaluation and assessment is not enough with the teacher's own efforts, but it is necessary from various parties such as supervisors, school principals, and other experts, such as research conducted by (Utami et al., 2020) showing that educators and education staff need to improve special competence in the field of evaluation and assessment as well as the care of supervisors or supervisors of institutions and related institutions in supervising and fostering institutions for improving the quality of education.

\section{Conclusion and Recommendation}

Based on research conducted to find out the controversy of pedagogical competence of Early Childhood Education teachers on the seven pedagogical competency criteria in the Ministry of Indonesia National Education 2010, it was found that the average controversy in Bengkulu City and Kepahiang District the biggest controversy was found in the "Teachers master learning activities that educate" while the smallest is in the criterion "Teachers master communication with students". The results of this study can be used by policy maker as input to provide guidance or training for Early Childhood Education teachers in cities and districts as an effort to improve their pedagogical competencies. It also may be useful as a reference by the government in formulating programs to overcome low teacher pedagogical competence.

\section{References}

Ananda, R., \& Fadhilaturrahmi, F. (2018). Peningkatan Kemampuan Sosial Emosional Melalui Permainan Kolaboratif pada Anak KB. Jurnal Obsesi : Jurnal Pendidikan Anak Usia Dini, 2(1), 20. https://doi.org/https://doi.org/10.31004/obsesi.v2i1.3

Andriana, J., Sumarsih, S., \& D, D. (2018). Kinerja Guru PAUD Ditinjau Dari Kualifikasi Pendidik, Pengalaman Mengajar, Dan Pelatihan. Jurnal IImiah Potensia, 3(2), 18-23. https://doi.org/https://doi.org/10.33369/jip.3.2.83-88

Anggraini, W., Nasirun, M., \& Yulidesni, Y. (2020). Penerapan Strategi Pemecahan Masalah dalam Meningkatkan Kemampuan Kognitif pada Anak Kelompok B. Jurnal IImiah Potensia, 5(1), 31-39. https://doi.org/https://doi.org/10.33369/jip.5.1.31-39

Aprinawati, I. (2017). Penggunaan Media Gambar Seri Untuk Meningkatkan Kemampuan Berbicara Anak Usia Dini. Jurnal Obsesi : Jurnal Pendidikan Anak Usia Dini, 1(1), 12 18. https://doi.org/10.31004/obsesi.v1i1.33

Apriyanti, H. (2017). Pemahaman Guru Pendidikan Anak Usia Dini Terhadap Perencanaan Pembelajaran Tematik. Jurnal Obsesi : Jurnal Pendidikan Anak Usia Dini, 1(2), 111117. https://doi.org/10.31004/obsesi.v1i2.22

Arsa, D., Atmazaki, A., \& Juita, N. (2019). Literasi Awal pada Anak Usia Dini Suku Anak Dalam Dharmasraya. Jurnal Obsesi: Jurnal Pendidikan Anak Usia Dini, 3(1), 127-136. https://doi.org/10.31004/obsesi.v3i1.159

Aulina, C. N. (2018). Penerapan Metode Whole Brain Teaching dalam Meningkatkan Motivasi Belajar Anak Usia Dini. Jurnal Obsesi: Jurnal Pendidikan Anak Usia Dini, 2(1), 1. 
https://doi.org/10.31004/obsesi.v2i1.1

Ayuni, D., \& Setiawati, F. A. (2019). Kebun Buah Learning Media for Early Childhood Counting Ability. Jurnal Obsesi: Jurnal Pendidikan Anak Usia Dini, 3(1), 1. https://doi.org/10.31004/obsesi.v3i1.128

Azzahra, N. A., Hardika, H., \& Kuswandi, D. (2019). Pola Komunikasi Guru Dalam Pembelajaran Anak Usia Dini. Jurnal Pendidikan: Teori, Penelitian, Dan Pengembangan, $4(2)$,

$137-142$. https://doi.org/http://dx.doi.org/10.17977/jptpp.v4i2.11917

Babuta, A. I., \& Rahmat, A. (2019). Peningkatan Kompetensi Pedagodik Guru Melalui Pelaksanaan Supervisi Klinis Dengan Teknik Kelompok. Al-Tanzim: Jurnal Manajemen Pendidikan Islam, 3(1), 1-28. https://doi.org/10.33650/al-tanzim.v3i1.496

Botutihe, S. N. (2020). Pola Pengelolaan Pendidikan Anak Usia Dini di Kota Gorontalo. Jurnal Obsesi: Jurnal Pendidikan Anak Usia Dini, 4(2), 883-891. https://doi.org/10.31004/obsesi.v4i2.481

Ciptaningtyas, A., Yetti, E., \& Hartati, S. (2020). Metode Pelatihan dan Persistensi Berpengaruh terhadap Kompetensi Pedagogik Guru PAUD. Jurnal Obsesi : Jurnal Pendidikan Anak Usia Dini, 4(2), 686-651. https://doi.org/10.31004/obsesi.v4i2.440

Dewi, I., \& Suryana, D. (2020). Analisis Evaluasi Kinerja Pendidik Pendidikan Anak Usia Dini di PAUD Al Azhar Bukittinggi. Jurnal Obsesi : Jurnal Pendidikan Anak Usia Dini, 4(2), 1051-1059. https://doi.org/10.31004/obsesi.v4i2.465

Fahmi, F., Syabrina, M., Sulistyowati, S., \& Saudah, S. (2021). Strategi Guru Mengenalkan Konsep Dasar Literasi di PAUD Sebagai Persiapan Masuk SD/MI. Jurnal Obsesi: Jurnal Pendidikan Anak Usia Dini, 5(1), 931-940. https://doi.org/10.31004/obsesi.v5i1.673

Fatimah, D. F., \& Rohmah, N. (2016). Pola Pengelolaan Pendidikan Anak Usia Dini di PAUD Ceria Gondangsari Suowono Jawa Tengah: Tahun Pelajaran 2015-2016. Manageria : Jurnal Manajemen Pendidikan ISlam, 1(2), 247-273. https://doi.org/https://doi.org/10.14421/manageria.2016.12-05

Fauziarti, B. F., \& Soedarsono, F. (2014). EFEKTIVITAS PELATIHAN KURIKULUM PENDIDIKAN ANAK USIA DINI DI KECAMATAN GRABAG. Pendidikan Dan Pemberdayaan Masyarakat, 1(2), 174-186. https://doi.org/https://doi.org/10.21831/jppm.v1i2.2687

Febrianta, Y., \& Fauzan, A. (2019). Hambatan Komunikasi Guru Pada Proses Pembelajaran Pendidikan Jasmani Di Sd Negeri Se-Kecamatan Kembaran. Dinamika Jurnal IImiah Pendidikan Dasar, 11(1), 27. https://doi.org/10.30595/dinamika.v11i1.5982

Halim Yustiyawan, R., Supriyanto, A., \& Mustiningsih. (2016). Hubungan Pengembangan Karir, Kompetensi Profesional, Dan Motivasi Kerja Dengan Kinerja Guru Paud Di Kecamatan Driyorejo Kabupaten Gresik. Jurnal Pendidikan: Teori, Peneltian Dan Pengembangan, https://doi.org/http://dx.doi.org/10.17977/jp.v1i7.6545 1297-1304.

Hasanah, I. (2015). Kurikulum Pendidikan Anak Usia Dini. Konstruktivisme: Jurnal Pendidikan \& Pembelajaran, 7(2), 155-163. https://doi.org/10.30957/konstruk.v7i2.314

Inikah, S. (2015). Pengaruh Pola Asuh Orang Tua Dan Kecemasan Komunikasi Terhadap Kepribadian Peserta Didik. Jurnal Bimbingan Konseling Islam, 6(1), 19-40. https://doi.org/http://dx.doi.org/10.21043/kr.v6i1.1038

Ismawati, D., \& Prasetyo, I. (2021). Efektivitas Pembelajaran Menggunakan Video Zoom Cloud Meeting pada Anak Usia Dini Era Pandemi Covid-19. Jurnal Obsesi : Jurnal Pendidikan Anak Usia Dini, 5(1), 665-675. https://doi.org/10.31004/obsesi.v5i1.671 
Janus, M., \& Brinkman, S. (2010). Evaluating early childhood education and care programs. International Encyclopedia of Education, 25-31. https://doi.org/10.1016/B978-0-08044894-7.01197-0

Junanto, S., \& Kusna, N. A. A. (2018). Evaluasi Program Pembelajaran di PAUD Inklusi dengan Model Context, Input, Process, and Product (CIPP). Inklusi: Journal of Disability Studies, 5(2), 179-194. https://doi.org/10.14421/ijds.050202

Khotimah, S. H., Sunaryati, T., \& Suhartini, S. (2021). Penerapan Media Gambar Sebagai Upaya dalam Peningkatan Konsentrasi Belajar Anak Usia Dini. Jurnal Obsesi : Jurnal Pendidikan Anak Usia Dini, 5(1), 676-685. https://doi.org/10.31004/obsesi.v5i1.683

Komara, I. B. (2016). Hubungan antara Kepercayaan Diri dengan Prestasi Belajar dan Perencanaan Karir Siswa SMP. PSIKOPEDAGOGIA Jurnal Bimbingan Dan Konseling, 5(1). https://doi.org/10.12928/psikopedagogia.v5i1.4474

Liempd, I. H. van, Oudgenoeg - Paz, O., \& Leseman, P. P. M. (2020). Do spatial characteristics influence behavior and development in early childhood education and care? Journal of Environmental Psychology, 67. https://doi.org/10.1016/j.jenvp.2019.101385

Maiza, Z., \& Nurhafizah, N. (2019). Pengembangan Keprofesian Berkelanjutan dalam Meningkatkan Profesionalisme Guru Pendidikan Anak Usia Dini. Jurnal Obsesi : Jurnal Pendidikan Anak Usia Dini, 3(2), 356-365. https://doi.org/10.31004/obsesi.v3i2.196

Mena, Y., Supriyanto, A., \& Burhhanudin, B. (2016). Pelaksanaan Supervisi Klinis Dalam Meningkatkan Mutu Kinerja Guru Di Sekolah Dasar. Jurnal Pendidikan - Teori, Penelitian, Dan Pengembangan, 1(11), 2194-2199. https://doi.org/10.17977/jp.v1i11.8074

Meutia, V., \& Mursita, R. A. (2018). Kompetensi Pedagogik Guru Kelas Dalam Pembelajaran Peserta Didik Tunarungu. Cakrawala Dini: Jurnal Pendidikan Anak Usia Dini, 9(1), 1927. https://doi.org/10.17509/cd.v9i1.11345

Mundia Sari, K., \& Setiawan, H. (2020). Kompetensi Pedagogik Guru dalam Melaksanakan Penilaian Pembelajaran Anak Usia Dini. Jurnal Obsesi : Jurnal Pendidikan Anak Usia Dini, 4(2), 900-912. https://doi.org/10.31004/obsesi.v4i2.478

Munir, A. (2016). Hubungan Antara Tingkat Kecemasan Berkomunikasi Dengan Kemampuan Beradaptasi Mahasiswa Asing di Universitas Negeri Medan tahun akademik 2013/2014. Jurnal Diverstita, 2(1). https://doi.org/https://doi.org/10.31289/diversita.v2i1.504

Nihayah, U. (2015). MENGEMBANGKAN POTENSI ANAK: Antara Mengembangkan Bakat dan Ekploitasi. Sawwa: Jurnal Studi Gender, 10(2). https://doi.org/10.21580/sa.v10i2.1429

Nurdin, N., \& Anhusadar, L. O. (2020). Evaluasi Pelaksanaan Standar Proses di Satuan Pendidikan Anak Usia Dini. Jurnal Obsesi: Jurnal Pendidikan Anak Usia Dini, 4(2), 982-993. https://doi.org/10.31004/obsesi.v4i2.485

Nurjannah, N. (2017). MENGEMBANGKAN KECERDASAN SOSIAL EMOSIONAL ANAK USIA DINI MELALUI KETELADANAN. Hisbah: Jurnal Bimbingan Konseling Dan Dakwah Islam, 14(1). https://doi.org/https://doi.org/10.14421/hisbah.2017.141-05

Prasanti, D., \& Fitriani, D. R. (2018). Pembentukan Karakter Anak Usia Dini: Keluarga, Sekolah, Dan Komunitas? Jurnal Obsesi : Jurnal Pendidikan Anak Usia Dini, 2(1), 1319. https://doi.org/https://doi.org/10.31004/obsesi.v2i1.2

Rahardjo, M. M. (2016). Menciptakan High Level of Play Dalam Rencana Pembelajaran Anak Usia Dini. Scholaria: Jurnal Pendidikan Dan Kebudayaan, 6(3). https://doi.org/10.24246/j.scholaria.2016.v6.i3.p206-216 
Rahelly, Y. (2018). Implementasi Kurikulum 2013 Pendidikan Anak Usia Dini (Paud) Di Sumatera Selatan. JPUD - Jurnal Pendidikan Usia Dini, 12(2), 381-390. https://doi.org/https://doi.org/10.21009/JPUD.122.21

Rahmat, A., \& Maulana, Z. (2016). Meningkatkan Kreatifitas Guru Mengajar Melalui Supervisi Akademik Dengan Teknik Konseling Pertemuan Individual. Psympathic: Jurnal IImiah Psikologi, 2(1), 41-56. https://doi.org/10.15575/psy.v2i1.446

Robbins, S. P. (2008). Organizational Behavior Tenth Edition (Perilaku organisasi Edisi ke Sepuluh) (B. Molan (Ed.); Tenth Edit). PT Macacnan Jaya Cemerlang.

Rosyati, T., Saprudin, S., \& Alaydrus, A. S. (2020). Kinerja OCB pada guru PAUD ditinjau dari Educational leadership dan Integritas. Jurnal Obsesi : Jurnal Pendidikan Anak Usia Dini, 5(1), 201-211. https://doi.org/10.31004/obsesi.v5i1.513

Setiawan, D., \& Sitorus, J. (2017). URGENSI TUNTUTAN PROFESIONALISME DAN HARAPAN MENJADI GURU BERKARAKTER (Studi Kasus: Sekolah Dasar dan Sekolah Menengah Pertama di Kabupaten Batubara). Jurnal Cakrawala Pendidikan, 36(1), 122-129. https://doi.org/10.21831/cp.v36i1.11382

Sum, T. A., \& Taran, E. G. M. (2020). Kompetensi Pedagogik Guru PAUD dalam Perencanaan dan Pelaksanaan Pembelajaran. Jurnal Obsesi : Jurnal Pendidikan Anak Usia Dini, 4(2), 543-550. https://doi.org/10.31004/obsesi.v4i2.287

Tanama, Y. J., Supriyanto, A., Universitas, M. P., \& Malang, N. (2016). Implementasi Supervisi Klinis Dalam. Jurnal Pendidikan: Teori, Penelitian, Dan Pengembangan, 1(11), 22312235. https://doi.org/http://dx.doi.org/10.17977/jp.v1i11.8127

Utami, W. Y. D., Jamaris, M., \& Meilanie, S. M. (2020). Evaluasi Program Pengelolaan Lembaga PAUD di Kabupaten Serang. Jurnal Obsesi: Jurnal Pendidikan Anak Usia Dini, 4(1), 67-76. https://doi.org/10.31004/obsesi.v4i1.259

Wandi, Z. N., \& Mayar, F. (2020). Analisis Kemampuan Motorik Halus dan Kreativitas pada Anak Usia Dini melalui Kegiatan Kolase. Jurnal Obsesi : Jurnal Pendidikan Anak Usia Dini, 4(1), 351-358. https://doi.org/10.31004/obsesi.v4i1.347

Watini, S. (2019). Pendekatan Kontekstual dalam Meningkatkan Hasil Belajar Sains pada Anak Usia Dini. Jurnal Obsesi: Jurnal Pendidikan Anak Usia Dini, 3(1), 82-90. https://doi.org/10.31004/obsesi.v3i1.111

Widayati, J. R., Safrina, R., \& Supriyati, Y. (2021). Analisis Pengembangan Literasi Sains Anak Usia Dini melalui Alat Permainan Edukatif. Jurnal Obsesi : Jurnal Pendidikan Anak Usia Dini, 5(1), 654-664. https://doi.org/10.31004/obsesi.v5i1.692

Widodo, M. M., \& Ruhaena, L. (2018). Lingkungan Literasi Di Rumah Pada Anak Pra Sekolah. Indigenous: Jurnal Ilmiah Psikologi, 3(1), 1-7. https://doi.org/10.23917/indigenous.v3i1.3059

Yati, F., \& Yaswinda, Y. (2020). Penerapan Model Evaluasi CIPPO dalam Mengevaluasi Penyelenggaraan Lembaga PAUD. Jurnal Obsesi : Jurnal Pendidikan Anak Usia Dini, 4(1), 30-40. https://doi.org/10.31004/obsesi.v4i1.238

Zhang, Z., Pereira, J. R., Sousa-Sá, E., Okely, A. D., Feng, X., \& Santos, R. (2018). Environmental characteristics of early childhood education and care, daily movement behaviours and adiposity in toddlers: A multilevel mediation analysis from the GET UP! Study. Health and Place, 54, 236-243. https://doi.org/10.1016/j.healthplace.2018.10.008 